\title{
PRESIDENTIAL DOCTRINES AND STRATEGIES OF AMERICAN FOREIGN POLICY FROM 1947 TO 1965
}

This paper analyzes the most important doctrinal statements of American foreign policy from 1947 to 1965. Attention will be primarily focused on The Truman Doctrine, the writings by George F. Kennan, The Eisenhower Doctrine and the Johnson Doctrine. These statements of US foreign policy constituted broader strategy of containment of Communism during the first two decades of the Cold War. I shall argue that these declared doctrines and strategies provided theoretical background for containment of the Soviet influence on a global scale. Also, the doctrines and strategies provided basis for active involvement of the United States in the regions where there was an imminent danger of Communist expansion.

Key words: Containment, Doctrine, The Cold War, The United States of America.

\section{Introduction}

No nation in modern history has relied on doctrines or foreign policy statements that defined its stance towards the outer world as the most powerful state in the international system - the USA. American doctrinal thought after the Second World War to a great degree guided the course of foreign affairs in the USA as well as in the world.

This paper concentrates on the analysis of main political-military doctrines of administrations of American presidents from the end of the 1940's, throughout the 1950's and the 1960's that formed the attitude of the United States towards strategic areas of interests from its view. The Truman doctrine, the writings by George F. Kennan, the strategy of "containment" of Communism, the Eisenhower doctrine, and the Johnson doctrine will be of primary importance as they shaped the stance of particular US administrations to the international politics and mainly to containing of influence of the Soviet Union.

\section{Some notes on the notion of "doctrine"}

C. V. Crabb [1, p. 11] defines doctrine of foreign policy in the American perception as "a statement of general principles. In nearly every case its issuance was precipitated by a foreign crisis or a specific set of circumstances abroad to which the United States was required to respond.”

A doctrine of foreign policy can also be viewed as an official conception of using the state's power in the international sphere. Therefore, such a doctrine constitutes a basis for adopting con- ceptions of particular aspects of power, for the strategy of diplomatic activity, political-military strategies and also for strategy of propaganda.

R. E. Osgood [2, p. 4] attributes to presidential doctrines of foreign policy the "central role in U.S. foreign policy."

\section{American doctrinal thought before the enunciation of the Truman Doctrine}

Since the first half of the nineteenth century, the United States has had a tendency to embody main elements of its foreign policy in diplomatic doctrines. The dominating principle that was common for all presidential doctrines before the Truman Doctrine was isolationism which reflected American attitude mainly to Europe. The United States strongly refused foreign interference within its affairs. The isolationist stance was reflected mainly in the Monroe Doctrine and also in The Monroe Doctrine Corollary.

\section{The Monroe Doctrine}

The defining pronouncement of the refusal was the Monroe Doctrine, enunciated by President James Monroe on December 2, 1823. This doctrine was perceived as a set of principles that later came to define American isolationist policy towards European powers. The enunciation of the Monroe Doctrine initiated a new period of relationship towards Europe. The United States, that was weaker at that time and did not have the status of superpower, made use of the situation in Europe, however, in a way that was rather ambivalent. On the one hand, the USA formulated a require-

\footnotetext{
* Marek Hampl

Department of English Language and Literature, Faculty of Science, University of Zilina, Slovakia, E-mail: marek.hampl@fpv.uniza.sk
} 
ment for European powers not to intervene within the affairs of Latin America, but on the other, it claimed a dominant status in the whole Western hemisphere. The United States expanded into regions where there was a power vacuum and to regions without influence of European powers.

\section{The Roosevelt Corollary to the Monroe Doctrine}

The Roosevelt Corollary is considered as an extension of the Monroe Doctrine. This corollary was declared by President Theodore Roosevelt on December 6, 1904. Roosevelt's speech was directed to the region of the Caribbean that was experiencing a period of political instability, upheaval and the rule of dictatorship regimes. These countries were indebted to European creditors. As a result, there was a danger of intervention from Europe because creditors intended to recover the debts. However, this was considered unacceptable by the United States. Roosevelt [3] declared:

"Chronic wrongdoing, or an impotence which results in a general loosening of the ties of civilized society, may in America, as elsewhere, ultimately require interventions by some civilized nations, and in the Western Hemisphere the adherence of the United States to the Monroe Doctrine may force the United States, however reluctantly, in flagrant cases of such wrongdoing or impotence, to the exercise of an inter national police power."

As it can be seen from this declaration, President Roosevelt assured Europe that the Western Hemisphere was the sphere of influence that could not be attacked by any European power, which marked the evolution of the Monroe Doctrine. The Roosevelt corollary was significant in that it made the USA intervene on about sixty occasions in Latin America. This corollary had only regional character, because it was mainly the smaller countries of the Caribbean and Central America in which it intervened.

\section{The Strategy of Containment of Communism}

In 1947, The Soviet Union, having the status of the only power that could challenge the United States, was perceived as the greatest threat to international security and also to American interest in the post-World War II world. Thus, a requirement emerged to contain Soviet expansionism and a system that was based on different set of economic and social values. The strategy whose purpose was to execute this came to be known as "containment." For successful implementation of this strategy, the United States had to support its vulnerable allies and friendly states with a variety of programs and to assist them in their modernization. All this was aimed to forbid the Soviet Union the position of the status of the world hegemon. J. L. Gaddis [4, p. 4] characterizes the strategy of containment as follows:

"Containment is the term generally used to characterize American policy toward the Soviet Union during the postwar era, and can be seen as a series of attempts to deal with the consequences of World War II. The idea has been to prevent The Soviet Union from using the power and position it won as a result of that conflict."

M. P. Leffler and D.S. Painter [5, p. 24] perceive the strategy of containment in terms of propagation of economic benefits. In their view the strategy of containment was "long-term American effort to effectuate a liberal capitalist world order that would be responsive to American economic needs and receptive to the dissemination of American ideas, values, and institutions."

However, there was also a lack of clarity about the content of the policy of containment of Communism that led to different perceptions among American scholars. As argued by conservative thinkers R. Strauzs-Hupé and S. T. Possony [6, p. 679]:

"The concept of containment was never translated into a set of understandable, concrete, and workable propositions. The partisans of containment have yet to explain what they propose to do in order to halt or balance the rapid growth of the Soviet power machine or how, under the threat of atomic war, a policy of defensive and passive coexistence can preserve democracy and safeguard what Mr. Acheson called the very existence of all civilization ... and the safety of the free world."

The strategy of containment was officially formulated several times, although in rather general terms and quite vaguely. The attempts at the formulation of the containment strategy can be considered as the most important: The Truman Doctrine, the article "The Sources of Soviet Conduct" by George F. Kennan and "The Long Telegram" also by G. F. Kennan (1946). In addition to these statements, the memorandum of National Security Council NSC-68, is also seen as an important part of the containment strategy.

\section{The Truman Doctrine}

There are no doubts about the official character of the presidential statement from March $12^{\text {th }}, 1947$ in which the basic principles of the Truman Doctrine were formulated. This speech delivered by the president Harry S. Truman reasoned the willingness of his administration to provide support for the governments of Greece and Turkey. Similarly to the Monroe Doctrine, the Truman Doctrine was enunciated as a response to the immediate threat that the United States faced from abroad. This threat was constituted by the alleged Soviet interventionism in Greece and in Turkey.

Truman was convinced that international politics was dominated by a clash between two dissimilar systems of values. $\mathrm{He}$ stated that nations of the world were compelled to choose between alternative ways of life that were represented by the United States and the Soviet Union.

The crucial part of Truman's statement was:

"This is no more than a frank recognition that totalitarian regimes imposed on free peoples, by direct or indirect aggression, undermine 
the foundations of international peace and hence the security of the United States." [7, \& 30]

By this, Truman presented the essence of his speech: the security of the USA and peace in the world were mutually interconnected. The United States was about to take over the status of Great Britain as the main player in the Near East and also around the world. Thus, he indirectly suggested that the United States should assume the role of the world's policeman. When responding to the threat of totalitarianism, Truman stated that the United States had to respond firmly, but primarily through the means of economic assistance. He stressed that the situation in the Near East was serious, and that if Greece and Turkey fell, it would cause confusion and disorder in the entire Middle East region. Also, the fall of these countries would have had a profound effect on other countries in Europe.

\section{Analysis of the article by George F. Kennan - 'The Sources of Soviet Conduct'}

There were two seminal texts by American diplomat George F. Kennan published in 1946 and in 1947 that influenced the attitude of the Truman administration and stirred discussion about the nature of the Soviet Union. Both articles summarized the features of Soviet foreign policy, its main motives and ambitions.

George F. Kennan was a distinguished diplomat with realistic views on the Soviet Union and is considered as the "architect" of the strategy of containment. The two texts that he rendered provided a new direction for American foreign policy in the post World War II era. "The Long Telegram" (1946) that was sent from the embassy in Moscow proposed revolutionary viewpoints that influenced American foreign policy in the decades to follow. His first article, "The Sources of Soviet Conduct" was published under pseudonym Mr. $\mathrm{X}$ and is often viewed as a theoretical reasoning of the policy of containment.

In the article "The Sources of Soviet Conduct", G. F. Kennan depicted the picture of an aggressive Soviet Union driven by Communist ideology that had to be faced. The term "containment" was used for the first time in this article. The article was published in Foreign Affairs in July 1947. In this article, it was declared that "the main element of any U.S. policy toward the Soviet Union must be that of long-term, patient but firm and vigilant containment of Russian expansive tendencies."[8, § 29] G. F. Kennan presupposes that these tendencies are an outgrowth of Marxist-Leninist ideology as well as of circumstances that are associated with historical development of Russia. According to him, it is possible to expect "the Soviet pressure against the free institutions of the Western world" [9, Kreis, 2000, §30] in the near future.

G. F. Kennan does not recommend any confidential and reliable relationship with the Soviet Union. In his view, it is necessary to face the Soviet efforts by "adroit and vigilant application of counter-force at a series of constantly shifting geographical and political points, corresponding to the shifts and manoeuvres of
Soviet policy" $[10, \S 30]$. The purpose of this American counterpressure is not only to prevent the Soviet Union from further expansion, but according to G. F. Kennan,

"it is entirely possible for the United States to influence by its actions the internal developments, both within Russia and throughout the international Communist movement by which Russian policy is largely determined." [11, \& 30]

The whole concept of containment that G. F. Kennan outlined was viewed as a "strategic monstrosity" by W. Lippmann [12, p. 18]. W. Lippmann also criticized the notion of unalterable counter-force that was proposed by G. F. Kennan.

Furthermore, W. Lippmann [13, p. 21] observed that this force could not be put together only by American troops and American military potential. Thus, he noted that it had to be "composed of Chinese, Afghans, Iranians, Turks, Kurds, Arabs, Greeks, Italians, of anti-Soviet Poles, Czechoslovaks, Bulgarians, Yugoslavs, Albanians, Hungarians, Finns and Germans" [14, p. 21].

In addition to this measure, W. Lippmann [15, p. 21] also proposed "supporting a heterogeneous array of satellites, clients, dependents and puppets." But he came to the conclusion that these instruments of the policy of containment would paradoxically result into "a coalition of disorganized, disunited, feeble or disorderly nations, tribes and factions around the perimeter of the Soviet Union” [16, p. 21]. Thus, he called for formation of modern states that could challenge the Soviet Union. Finally, he criticized G. F. Kennan's perception of the function of diplomacy: "For a diplomat to think that rival and unfriendly powers cannot be brought to a settlement is to forget what diplomacy is about." [17, p. 21]

However, this important statement by G. F. Kennan defined the strategy of containment as the basic American principle towards the Soviet Union. It can be also interpreted as an appeal to buildup military bases along the borders of the Soviet Union. And finally, it also conveyed an intellectual reasoning of the containment itself and introduced this strategy to public focus.

G. F. Kennan's main contribution lies in the fact that he formulated the requirement for transition from isolationistic ideas about "Fortress America" to interventional dreams about "Pax Americana". The former concept was associated with right-wing neo-isolationists and presupposed that the United States could protect its own security although there were political turbulences abroad.

A different perception and criticism of the strategy of containment was proposed by W. Lippmann who had formulated the conception of Soviet-American relations already during the World War II. His views were different to those of G. F. Kennan. W. Lippmann [18, p. 95] assumes that the history of relations between Russia and the

United States proved that it was not ideology but national interest that was crucial for the line of foreign policy. This resulted 
from the fact that Russia and the United States always took opposing stances in regard to particular ideology, but at the same time they considered each other as potential allies behind the lines of a potential enemy. [19, p. 95]

W. Lippmann [20, p. 29] strongly condemns the policy of containment proposed by G. F. Kennan by claiming:

"my objection, then, to the policy of containment is not that it seeks to confront the Soviet power with American power, but that the policy is misconceived, and must result in a misuse of American power. For as I have sought to show, it commits this country to a struggle which has for its objective nothing more substantial than the hope that in ten or fifteen years the Soviet power will, as the result of long frustration, 'break up' or 'mellow'."

W. Lippmann [21, p. 28] also held the opinion that it was necessary to confront the Soviet Union with American power, but he assumed that "a policy of containment does not contain", and that "measures of counterforce are doomed to be too late and too little."

\section{The stance of American conservatives towards the strategy of containment of communism}

The conservatives and isolationists in the USA perceived the policy of containment as being too defensive for the needs of the United States. In their view, the whole strategy did not grasp the essence of the Soviet power and the fundamental principles of Soviet system. Therefore, they thought that it was aimless. They did not perceive as a unified concept, because it preferred containing Communism mainly in Europe and actually led to the "loss" of China in 1949. This stance is supported by R. StrauszHupé and S.T. Possony [22, p. 670] who assume that "it is unnecessary to stress the fact that the stakes in China were far greater than those in Greece or even Turkey", and that "the United States allocated to individual European countries sums that were much larger than total of Chianng's share" who was directly involved in the fight against Communism. Therefore, R. Strausz-Hupé and S. T. Possony [23, p. 678] presuppose that "the policy of containment and coexistence leaves the initiative in the Soviet hands." Similar standpoint can be found in J. Burnham [24, p. 30] who is of opinion that "a defensive policy - and containment is a variant of the defensive - can never win."

We can conclude that American conservatives paradoxically saw the strategy of containment as a mere reaction to Soviet initiatives or as a formula to overall Soviet victory. Moreover, containment was perceived as a variation of defensiveness that could be hardly applicable worldwide.

\section{The Eisenhower Doctrine}

The Eisenhower Doctrine is in its essence similar to the Truman Doctrine, however, the main difference between them lies in the fact that the Eisenhower doctrine led to military involvement of
USA in the Middle East, whereas the Truman Doctrine got the US involved in the Korean War. Nevertheless, this doctrine bears similarity to the Truman Doctrine and it can be said that it is actually an extension of the Truman Doctrine and of the containment strategy, however, specifically designed for the region of the Middle East.

President Dwight David Eisenhower enunciated his doctrine on January 5, 1957, before a joint session of the Congress, at the beginning of his fifth year in the office.

Eisenhower in his speech stated the chief principles of American foreign policy after the defeat of intervention of Great Britain and France in the Suez Crisis. Britain and France wanted by join forces to overthrow Egypt's nationalization of the Suez Canal, however, they were not successful.

The Suez Crisis of 1956 significantly changed the political map of the Middle East and accelerated the rise of Arab nationalism in the region. The result of the Suez Crisis set the stage for the framework of the Eisenhower Doctrine. Also, the Soviet Union for a brief period of time considered a possibility of intervention on the Egypt's side in this crisis, which only intensified the US efforts to secure this strategic region. Eisenhower asked the Congress for 200 million dollars a year for three years for help to nations of the Middle East. The purpose of this aid was to secure "any nation or group of nations in the general area of the Middle East the development of economic strength dedicated to the maintenance of national independence.” $[25, \S 17]$

Apart from economic and military assistance to pro-American regimes, Eisenhower in his speech demanded to protect "the territorial integrity and political independence of such nations, requesting such aid, against covert armed aggression from any nation controlled by International Communism.” [26, §19] Thus, Eisenhower similarly to Truman indirectly suggested taking over the role of the world leader that had been occupied by the British Empire up to then. Formulations about an effort to avoid other conflicts similar to the Korean War were accompanied by the program that denounced the conceptions of containment and rather adhered to the firm conservative conceptions of 'liberation'.

The Eisenhower administration feared that the power vacuum created by withdrawal of Great Britain from the area would be filled by Communism. As argued by R. Takeyh [27, p. 110] filling this vacuum could give Russia an "opportunity to improve its position in an area having vital resources and strategic location." This also caused anxiety of Washington about the security in the Middle East.

In reference to the Soviet Union, Eisenhower presented Communist aggression as being imminent in the region of the Middle East. He named two relevant reasons why the United States should engage in the area of the Middle East. International Communism, according to Eisenhower, had always aspirations to dominate the region of the Middle East. The second reason that was provided by Eisenhower concerned the alleged expansiveness of the Soviet 
regime that intended to gain control of the Middle East area Eisenhower highlighted the cases of Estonia, Latvia and Lithuania that were "forcibly incorporated into the Soviet Union" [28, $\S 8$ ] as well as Soviet control of the satellite nations of Eastern Europe as a proof of his claim about expansiveness of the Soviet regime.

The secondary aim of the doctrine was reduction of the rising influence of Egypt that was about to take the role of the leader of Arab world. Egyptian president Gamal Abdul Nasser was considered as an embodiment of Arab nationalism. Also, as put by R. Takeyh [29, p. 142], Nasser had positive attitude to the Soviet Union and was thought to be an extension of Soviet influence in the Middle East. Nasser was the most popular leader in Arab world and an "undisputed embodiment of the region's historical quest for self-determination." A broad movement that was known as "Nasserism" was perceived by the officials in the Eisenhower administration as the next thing to Communism. By depicting Nasser as a collaborator with the Soviet Union, the United States could legitimize its intended measures and policy. Nasser also strongly condemned Western imperialism, which worried Washington.

W. Lippmann (1947) observed that purpose of the eloquence of the doctrine was actually to give the Secretary of State John Foster Dulles a free hand in his actions. The closest ally of the United States - The British, had a different perception of the Soviet threat in the Middle East. They did not see any imminent threat from the Soviet side and wondered whether a new arms race was starting in the Middle East. The rhetoric of the doctrine was even perceived in Europe as a final step towards a kind of the hegemony of the United States.

The Eisenhower doctrine undoubtedly presented an attempt to gain allies from the area of the Middle East into the sphere of influence of the USA in the global struggle against the Soviet Union. It is undeniable that the Eisenhower administration also accepted the logic of the strategy of containment.

However, as a part of the containment policy, the Eisenhower Doctrine also had certain weaknesses. It is questionable whether the doctrine prevented Soviet influence from penetrating into the region of the Middle East. Also, the basic premise on which the doctrine was built-up, i.e., filling the power vacuum in the Middle East was rather offensive to Arabs and partly contributed to polarization of the region.

\section{The Johnson Docrine}

There are several foreign-political doctrines that are associated with the presidency of Lyndon B. Johnson. C. V. Crabb [30, p. 4] suggests that there were actually two Johnson Doctrines enunciated: a declaration made by Johnson in August 1964 about the necessity to "take all necessary measures in support of freedom and in defence of peace in South Asia" [31, p. 4]. This doctrine came to be known as the Gulf of Tonkin Resolution which legit- imized American military involvement in Vietnam. Similarly to all doctrines discussed so far, this doctrine was also enunciated as a reaction to a perceived crisis abroad.

When American naval units were attacked in the Gulf of Tonkin on August 4, 1964, President Johnson said that the United States was prepared to

"take all necessary steps, including the use of armed force, to assist any member of protocol member of the Southeast Asia Collective Defense Treaty requesting assistance in defense of its freedom." [32, p. 19]

Johnson asked the Congress to affirm that "all such attacks will be met." $[33, \S 12]$. Finally, the Congress passed the Gulf of Tonkin Resolution which stated that "the Congress approves and supports the determination of the President, as Commander in Chief, to take all necessary measures to repel any armed attack against the forces of the United States“ $[34, \S 15]$.

The text of the Gulf of Tonkin Resolution stated that "Congress approves and supports" efforts executed by President to "take all necessary measures designed to repel attacks upon American military units. Also, the stress was placed "to prevent further aggression.” $[35, \S 15]$.

As it can be seen from the rhetoric of the doctrine, the main purpose of the Johnson Doctrine was to present a united American stance towards the world. The doctrine was designed to have a deterrent effect on North Vietnam and also on other Communist states supporting North Vietnam. Also, the doctrine was intended to highlight the importance of American commitments in Southeast Asia that were defined in the Southeast Asia Collective Defense Treaty that was signed in February 1955. According to Johnson, this treaty "obligates the United States and other members to act in accordance with their constitutional processes to meet Communist aggression."

\section{Conclusion}

From the analysis above, we can conclude that the strategy of containment of Communism became the crucial element of American foreign policy and diplomacy during the early Cold War period. As noted by P. Seabury [36, p. 39], "it is nevertheless true that one theory-that of containment served a whole generation of American decision-makers as the foundation of our foreign policy." Indeed, this strategy provided a theoretical framework for the American position in the Cold War. On the other hand, the Soviet Union did not accept American view of the containment strategy at all.

Containment of Soviet power and influence all over the world was considered as the most important aim of US foreign policy because the Soviet Union posed the greatest danger to US interests and security although the United States accepted the existence of the Soviet Union as a fact. According to the containment doctrine, the Soviet Union was seen as the chief enemy of world order. 
Nevertheless, as it can be seen from the analysis of the rhetoric of the presidential doctrines and documents that constituted the strategy of containment, this strategy became the principal objective of the United States and the presidential doctrines of that time were in their essence designed to stop Soviet expansion in the regions delineated by these doctrines.

At the end of the Second World War, the United States and the Soviet Union emerged as the two major powers that determined the situation in the international system [37]. During the following period of the Cold War, these superpowers competed in many areas, such as military or economic. As discussed in this article the notion of containment of Communism provided the basic American embodiment of relationship towards the Soviet Union in the early Cold War period. For most of the Cold War era, these two superpowers defined themselves as the most significant obstacle to the hegemony in the world for each other.

The Soviet Union with its allies and faithful agents tried to unite the Socialist countries - this was to be the means of how to stop capitalism. On the other hand, the United States of America, with its presidential and containment doctrines that were designed to confront the Soviet Union as well as with defense alliances and means of economic assistance (e.g., NATO, The Marshall Plan) was committed to confront the Communist movement.

American concept of security that stemmed mainly from presidential doctrines and strategies of National Security was during the Cold War active and in a certain sense missionary for the United States. This concept expanded in terms of geography from the end of World War II together with the growing global activity of the United States and helped to execute broader global goals. At the same time, it was mainly designed to confront the interests of the main rival - the Soviet Union. Beginning with the Truman Doctrine, continuing with the Eisenhower Doctrine and concluding with The Johnson Doctrines, each and every doctrinal statement enunciated in the USA in the first two decades of the Cold War also involved a strong assertion to the principles of ideology that were accepted by the main American political streams.

\section{References}

[1] CRABB, C. V.: The Doctrines of American Foreign Policy. Their Meaning, Role and Future, Baton Rouge, Lousiana University Press, 1982.

[2] OSGOOD, R. E.: Limited War Revisited. Colorado: Westview Press, 1979.

[3] cit. in CRABB, C. V., p.19

[4] GADDIS, J. L.: The Long Peace: Inquiries into the History of the Cold War, New York, Oxford University Press, 1987, New York, Oxford University Press, 1982. [Retrieved 2009]

[5] LEFFLER, M. P., PAINTER, D. S.: Origins of the Cold War: An International History, New York: Routledge, [Retrieved 2009], from Questia database: http://www.questia.com/ /PM.qst?a=o\&d=103369628, 1994

[6] STRAUSZ-HUPE, R., POSSONY, S. T.: International Relations in the Age of the Conflict between Democracy and Dictatorship, New York, McGraw-Hill. [Retrieved October 29, 2009] 〈http://www.questia.com/ PM.qst?a=o\&d=9303607〉, 1954.

[7] The Truman Doctrine. The Avalon Project, [Retrieved 2009] 〈http://avalon.law.yale.edu/20th_century/trudoc.asp〉

[8] KREIS, S.: George Kennan, "The Sources of Soviet Conduct"(1947). [Retrieved 2009], http://www.historyguide.org/Europe/kennan.html, 2000

[9] Ibid.

[10] Ibid.

[11] Ibid.

[12] LIPPMANN, W.: The Cold War, a Study in U. S. Foreign Policy, New York, Harper, [Retrieved 2009] http://www.questia.com/ PM.qst?a $=0 \& d=76910562,1947$

[13] Ibid.

[14] Ibid.

[15] Ibid.

[16] Ibid.

[17] Ibid.

[18] LIPPMANN, W.: Foreign Policy and Military Purposes of U.S.A. (in Czech), Praha, Vydavatelstvo Druzstevni prace, 1946.

[19] LIPPMANN, W.: The Cold War, a Study in U. S. Foreign Policy, New York: Harper, [Retrieved 2009] , <http://www.questia.com/ PM.qst?a=o\&d=76910562>, 1947.

[20] Ibid.

[21] Ibid.

[22] STRAUSZ-HUPE, R., POSSONY, S. T.: International Relations in the Age of the Conflict between Democracy and Dictatorship. New York: McGraw-Hill. [Retrieved, 2009] 〈http://www.questia.com/PM.qst?a=o\&d=9303607〉, 1954

[23] Ibid.

[24] BURNHAM, J.: The Coming Defeat of Communism, London, Jonathan Cape, 1950 
[25] HALSALL, P.: Modern History Sourcebook: The Marshall Plan, 1947, [Retrieved 2009], <http://www.fordham.edu/halsall/mod/ 1947marshallplan1.html>, 1998

[26] Ibid.

[27] TAKEYH, R.: The US, Britain and Nasser's Egypt, 1953-57, Basingstoke, Macmillan, 2000.

[28] HALSALL, P.: Modern History Sourcebook: The Marshall Plan, 1947, [Retrieved 2009], <http://www.fordham.edu/halsall/mod/ 1947marshallplan1.html>, 1998

[29] TAKEYH, R.: The US, Britain and Nasser's Egypt, 1953-57, Basingstoke: Macmillan, 2000.

[30] CRABB, C. V.: The Doctrines of American Foreign Policy. Their Meaning, Role, And Future, Baton Rouge, Lousiana University Press, 1982

[31] Ibid.

[32] cited in CRABB, C. V.: The Doctrines of American Foreign Policy. Their Meaning, Role, And Future. Baton Rouge: Lousiana University Press, 1982

[33] The Johnson Doctrine, The Tonkin Gulf Incident, 1964. [Retrieved 2009], 〈http://avalon.law.yale.edu/20th_century/tonkin-g.asp >, 1982.

[34] Ibid.

[35] Ibid.

[36] SEABURY, P.: Reinspecting Containment, Beyond Containment, Alternative American Policies Toward the Soviet Union, Ed.: A. Wildavsky, San Francisco, ICS Press, 1983.

[37] ZILOVA, Z.: The Role of Language in Denoting Expressing and Transforming the Reality Throughout the History of Knowledge, In: Journal of Interdisciplinary Philology (1), pp. 27-44, Faculty of Science, University of Zilina, 2010. 